\title{
Comparative bromatological analysis of Cecropia glaziovii Snethl leaf and its importance in the nutritional requirement of Bradypus variegatus from São Paulo, Brazil.
}

\section{Análise bromatológica comparativa da folha de Cecropia glaziovii Snethl e sua importância na exigência nutricional do Bradypus variegatus de São Paulo, Brasil.}

\author{
Erica Elias Baron ${ }^{1}$; Sandra Peres Ferreira ${ }^{1,2}$; Larissa Araújo Stabile ${ }^{1}$; Fernanda Freitas \\ Dominguez ${ }^{1}$; Juliana Plácido Guimarães ${ }^{1 *}$
}

\begin{abstract}
Brazilian landscapes have undergone extreme transformations due to deforestation. Consequently, the size and dynamics of Bradypus variegatus - the brown-throated three-toed sloth - populations are directly affected. These groups of mammals representing the superorder Xenarthra, have herbivorous and even insectivorous habits, showing food selectivity by the tree of the genus Cecropia spp. mainly the red leaves instead of the green ones. It is estimated that the three-fingered Bradypus variegatus consumes $15 \mathrm{~g}$ of dry food ( $\mathrm{kg} / \mathrm{day})$ during a dry season. This study aimed to compare by centesimal analysis the green and red leaves of the Embauba tree (Cecropia glazioviiSnethl) to understand the preference for the younger leaf, also known as tender/red. The results obtained for the red and green leaves were respectively: dry matter $21.29 \%$ and $31.17 \%$, ashes $9.18 \%$ and $11.05 \%$, ethereal extract $0.80 \%$ and $2.68 \%$, digestibility $23.14 \%$ and $23.15 \%$, Vit C $1.86 \mathrm{mg}$ and $1.35 \mathrm{mg}$, crude fiber $22.30 \%$ and $23.47 \%$ protein $16.54 \%$ and $14.55 \%$. From these results, it was possible to identify that the red leaf has higher levels of crude protein and moisture, allowing the understanding of the preference of Bradypus variegatus.
\end{abstract}

Keywords: Embauba tree; Bradypus variegatus; Cecropia glaziovii Snethl; Bromatological analysis.

\section{RESUMO}

As paisagens brasileiras passaram por transformações extremas devido ao desmatamento. Consequentemente, o tamanho e a dinâmica das populações de Bradypus variegatus - a preguiça de três dedos de garganta marrom - são diretamente afetados. Esses grupos de mamíferos que representam a superordem Xenarthra, possuem hábitos herbívoros e até insetívoros, apresentando seletividade alimentar pela árvore do gênero Cecropia spp. principalmente as folhas vermelhas em vez das verdes. Estima-se que o Bradypus variegatus de três dedos consuma $15 \mathrm{~g}$ de matéria seca $(\mathrm{kg} / \mathrm{dia})$ durante a estação seca. Este estudo teve como objetivo comparar por análise centesimal as folhas verdes e vermelhas da árvore Embauba (Cecropia glaziovii Snethl) para entender a preferência pela folha mais jovem, também conhecida como tenra/vermelha. Os resultados obtidos para as folhas vermelhas e verdes foram respectivamente: matéria seca $21,29 \%$ e $31,17 \%$, cinzas $9,18 \%$ e $11,05 \%$, extrato etéreo $0,80 \%$ e $2,68 \%$, digestibilidade $23,14 \%$ e $23,15 \%$, Vit C $1,86 \mathrm{mg}$ e $1,35 \mathrm{mg}$, fibra bruta $22,30 \%$ e $23,47 \%$ proteína $16,54 \%$ e $14,55 \%$. A partir desses resultados, foi possível identificar que a folha vermelha possui maiores teores de proteína bruta e umidade, permitindo entender a preferência de Bradypus variegatus.

\footnotetext{
${ }^{1}$ Centro Universitário São Judas Tadeu

*E-mail: juvetpg@yahoo.com.br
} 
Palavras-chave: Árvore de embaúba; Bradypus variegatus; Cecropia glaziovii Snethl; Análise bromatológica.

\section{INTRODUCTION}

Bradypus variegatus is a mammal native from Brazil, Bolivia, Colombia, Costa Rica, Ecuador Honduras, Nicaragua, Panama, Peru, Venezuela, and is possibly extinct in Argentina, commonly known as sloth with brown throat, three-fingered Bradypus variegatus and three-fingered Bradypus variegatus with brown throat (IUCN, 2014). This specimen belongs to the Animalia Kingdom, Filo Chordata, Mammal Class, Pilosa Order and Bradypodidae Family (IUCN, 2014). It is an animal considered arboreal with day or night habits, and it becomes extremely susceptible to attack by other animals when getting down to the ground from the trees (ICMBIO).

According to the evaluation of "The IUCN Red List of Threatened Species", three-fingered Bradypus variegatus occupies the category "Least Concern (LC)" due to its large population in South America.

These animals seek their food in various natural resources depending on their survival and maintenance from diet, both in quantity and quality. A good strategy for the search and exploitation of food resources is one that maximizes nutritional gains in food and minimizes mortality risks (BIANCHI; MOREIRA, 2005).

Some studies developed with Bradypus variegatus of the Genus Bradypus in different ecosystems and in conditions of semi-captivity (MONTGOMERY; SUNQUIST, 1978; EISENBER; MALINIAK, 1985; QUEIROZ, 1995; CHIARELLO, 1998; CONSENTINO, 2004) showed food selectivity, which means that of several species of available plants the animals fed on only a few. The studies also overturned paradigms, such as the diet composed exclusively of Cecropia sp.

Montgomery and Sunquist (1975) shows that B. variegatus prefer young leaves because they have greater digestibility and suggested that among them there is a selection of leaves in the diet according to the chemical composition and it was also concluded that the animals use non-taxonomic patterns for this selection. The Bradypus demonstrated to select more tall trees, with the canopy exposed to the sun and many vines. 
The interest in different plant species already described in the literature, as well as their ingestion, are determined both by social factors, such as the food preference learned from the mother, and by the availability of resources linked to the environment and associated with smell. And there are also those resulting from evolutionary processes (SILVA, 2017).

Nutritional and digestive problems in captive sloths occur in about $45.7 \%$ and $12.3 \%$, respectively. The most frequent clinical signs are diarrhea, constipation, and tympanism (MIRANDA, 2014).

The species Bradypus variegatus has tree habits, herbivores, with a high level of food specificity, which uses young and mature leaves. Sloths have a differentiated eating habit, a great complement to their diet is leaves. Being its favorable dentition allowing the leaves to be shredded in small pieces (CARTELLE, 2000).

Sloths of the genus B. variegatus are specialized gastric fermenters. They have a dilated stomach that is partially divided into 4 cavities where microbial fermentation of plant compounds occurs. They present the small intestine short and absence of cecum. The interval between the intake of food that passes slowly through the digestive tract, until defecation takes about 150 hours (CUBAS, 2006).

There is a great preference manifested by sloths by young leaves, which have lower proportions of hard-to-digest compounds such as cellulose, tannins, alkaloids and lignin, and have higher concentrations of sugars, water and proteins when compared to mature leaves (PINHEIRO, 2008).

Leaves may present concentrations of compounds and nutrients varied depending on various factors such as period of day, annual seasons, senescence and tree position (QUEIROZ, 1995).

Cecropia pachystachya Trécul (embauba) is a plant in the Urticaceae family (HERNANDEZ-TERRONES et al, 2007). The embauba is also known as the "sloth tree". This is due to the preference of this species (DIAS, 2017).

Cecropia pachystachya Trécul can appear in several plant formations, such as primary and humid forests of the semideciduous forest, river banks and riparian forests (DIAS, 2017).

The trees are 15 meters high, the plants have fistulous stems (hollows between the nodes) with many ants. The leaves are inserted in the spirally shaped branches and 
present long and whitish petioles, with arachnoid hairs (trichomes), similar to spider webs (HEURET et al., 2002).

Embauba leaves are highly appreciated by Bradypus variegatus, since it contains high concentration of steroids and flavanic substances in leaves and stems. Phytochemical analysis reveals the presence of reducing sugars, foamy saponin, proteins and amino acids, catech tannins, coumarin derivatives, steroids and triterpenoids (PEREIRA, 2015).

Figure 1. Graphical Abstract Image showing the preferences.

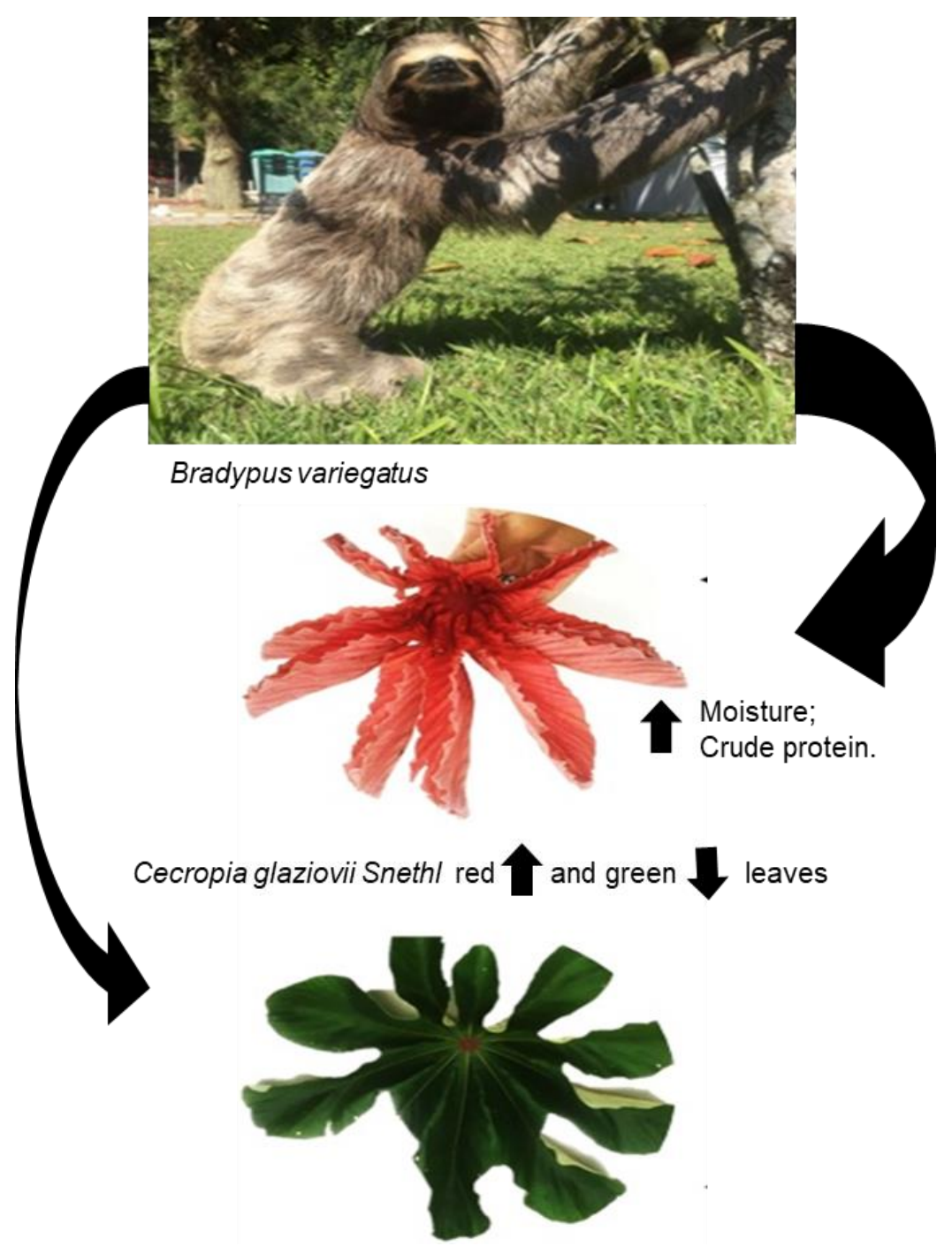

Fonte: Baron, Peres \& Guimarães (2019)

\section{MATERIAL AND METHODS}


Red and green embauba (Cecropia glaziovii Snethl) leaves from different strata from the same trees were collected in land adjacent to the Engenheiro Tércio Augusto Garcia Junior Ecological Park (Coordinates: -23.960148, -46.365437).

In order to compare the nutritional components of the young red leaves preferred by the sloths in relation to the more mature and green leaves, the analyses of dry matter, mineral matter, ether extract, digestibility in pepsin $0.2 \%$, vitamin $\mathrm{C}$ or ascorbic acid, crude fiber and crude protein in triplicates were performed. Weende methodology was used to perform bromatological analysis, with the exception of crude protein, which was performed using the Micro Kjeldahl and vitamin C methodology, which was by titration of iodine oxide reduction.

We used 417.63 grams of red embauba leaf and 311.86 grams of green embauba leaf that were crushed. For the bromatological analysis of dry matter, a greenhouse at $100^{\circ} \mathrm{C}$ was used for 16 hours. The analysis of mineral matter occurred from the use of muffle at $400^{\circ} \mathrm{C}$ for 5 hours. The ethereal extract was determined using $50 \mathrm{~mL}$ of petroleum ether by hot extraction for about 1 hour.

For digestibility, $150 \mathrm{~mL}$ of $0.2 \%$ pepsin solution was used in an oven at $45^{\circ} \mathrm{C}$ for about 16 hours. The amount of vitamin $\mathrm{C}$ or ascorbic acid was established in food from the oxireduction reaction between iodine and starch.

Crude fiber analysis was performed by acid hydrolysis with sulfuric acid for 60 minutes and basic hydrolysis with sodium hydroxide for another 60 minutes. Crude protein was quantified from leaf digestion for 4 hours.

The significance of the bromatological differences between the two types of leaves was evaluated with the t-student test for independent samples. The assumptions of this statistical method, namely the normalities of the distributions and the homogeneity of variances in the two groups were also evaluated. The SPSS Software was used (v. 14; SPSS Inc, Chicago, IL) to perform the test, and the differences between means whose $\mathrm{p}$-value of the test was less than or equal to 0.05 are considered statistically significant. The results are presented as standard mean and error of the mean (SEM).

\section{RESULTS}


The results obtained from the bromatological analyses for younger red leaf were: dry matter (DM) $21.29 \%$, ashes (AS) $9.18 \%$, ethereal extract (EE) $0.80 \%$, digestibility (DG) $23.14 \%$, Vit C (VC) $1.86 \mathrm{mg}$, crude fiber (CF) $22.30 \%$ and protein (PT) $16.54 \%$. For green leaf it was observed 31.17\% DM, 11.05\% AS, 2.68\% EE, 23.15\% DG, 1.35 $\mathrm{mg}$ (VC), $23.47 \% \mathrm{CF}$ and $14.55 \% \mathrm{PT}$.

According to the t-Student test, the differences observed between dry matter, ashes and ethereal extract were statistically significant. No differences were observed between crude protein, crude fiber, digestibility or vitamin $\mathrm{C}$. The values obtained were: $\mathrm{DM}-21.29 \% \pm 0.42$ and $31.17 \% \pm 0.19 ; \mathrm{p}=<.05)$, ashes $(\mathrm{AS}-9.17 \% \pm 0.18$ and $11.05 \% \pm 0.05 ; \mathrm{p}=0,05)$, ethereal extract $(\mathrm{EE}-0.79 \% \pm 0.0003$ and $2.67 \pm 0.12 ; \mathrm{p}$ $=0,05)$.

\section{CONCLUSION}

From these results, despite the difference between red and green embauba leaves, presenting differences in bromatological analyses for protein and digestibility, but not presenting statistical differences, we can consider that the consumption of red leaves is preferred by Bradypus variegatus, by color, moisture and softness over bromatological components. Due to the higher humidity and lower energy content, it is suggested the consumption of red leaves by captive animals to reduce gastrointestinal problems and tympanism.

\section{DISCLOSURE OF INTEREST}

The authors declare no conflict of interest.

\section{ACKNOWLEDGEMENTS}

We would like to thank the Engenheiro Tércio Augusto Garcia Junior Ecological Park and its collaborators who allowed the collection of plant samples and observation of the animals. To the technicians who assisted in the laboratory. To the São Judas 
University Center, which gave the laboratory to prepare the bromatological analyses and the reagents. To all who somehow collaborated to carry out the work.

\section{REFERENCES}

BIANCHI, V., MOREIRA G. R. Preferência alimentar, efeito da planta hospedeira e da diversidade larval na sobrevivência e desenvolvimento de Dione juno juno (Cramer) (Lepidoptera, Nymphalidae). Revista Brasileira de Zoologia, Curitiba, v. 22, n. 1, p. 43-50, Mar. 2005.

CARTELLE, C. Preguiças terrícolas, essas desconhecidas. Ciência Hoje, Rio de Janeiro, v. 27, n. 161, p. 18-25, 2000.

CHIARELLO, A. G. Diet of Atlantic Forest maned sloth Bradypus torquatus (Xenarthra: Bradypodidae). Journal Zoology, London, v. 246, n. 1, p. 11-19. Set. 1998.

CONSENTINO, L. N. Aspectos do comportamento da preguiça-comum, Bradypus variegatus (XENARTHRA, BRADYPODIDAE) em uma área de semi-cativeiro no município de Valença - Rio de Janeiro. 2004. 38f. Dissertação (Mestrado em Biologia Animal) Universidade Federal Rural do Rio de Janeiro, Seropédica. 2004.

CUBAS, Z. S., SILVA, J. C. R., CATÃO-DIAS, J. L. Tratado de animais selvagens Medicina Veterinária. São Paulo: Rocca, 2006, 1354 p.

DIAS, J. Wiki Aves. 2016. Disponível em:

<http://www.wikiaves.com.br/flora:embauba>. Acesso em: 29 de agosto de 2017.

EISENBERG, J. F., MALINIAK, E. Maintenance and reproduction of two-toed sloths Choloepus didactylus in captivity. In: MONTGOMERY, G.G. (Ed.). The Evolution and Ecology of Armadillos, Sloths and Vermilinguas. Washington and London: Smithsonian Institution Press, 1985. p. 337-331.

HERNANDEZ-TERRONES, M. G., MORAIS, S. A. L., LONDE, G. B., NASCIMENTO, E. A., CHANG, R. Ação alelopática de extratos de embaúba (Cecropia pachystachya Trec.) no crescimento de capim-colonião (Panicum maximum). Planta daninha, vol.25, n.4, pp. 763-769, 2007.

HEURET, P., BARTHÉLÉMY, D., GUÉDON, Y., COULMIER, X., TANCRE, J. Synchronization of growth, branching and flowering processes in the south american tropical tree Cecropia obtusa (Cecropiaceae). American Journal of Botany, v. 89, n. 7, p. 1180-1187, 2002.

MIRANDA, F. Cingulata (tatus) e pilosa (preguiças e tamnaduás). In: CUBAS, Z. S; SILVA, J. C. R; CATÃO-DIAS, J. L. Tratado de Animais Selvagens. 2 ed. São Paulo: Roca LTDA. vol. 1, cap. 33, p. 791-792, 2014. 
MONTGOMERY, G. G., SUNQUIST, M. E. Impact of sloths on the Neotropical Forest Energy Flow Nutrient Cycling. In: GOLLEY, F.B. \& MEDINA, E. Tropical Ecological Systems: Trends in Terrestrial and Aquatic Research. New York: Spring Verlag, p. 69-98, 1975.

MONTGOMERY, G. G.; SUNQUIST, M. E. Habitat selection and use by two-toed and three-toed sloths. In: MONTGOMERY G.G. (ed.) The ecology of Arboreal Folivores. Washington: Smithsonian Institution Press, p. 329-359, 1978.

PEREIRA, C. K. B. Determinação dos constituintes químicos e avaliação das atividades Biológicas da espécie Cecropia pachystachya Trécul (Urticaceae), 148 f. 2015.

PINHEIRO, S. D. Comportamento alimentar da preguiça comum Bradypus variegatus (Xenarthra, Bradypodidae) no Parque centenário de Barra Mansa - RJ. Juiz de Fora, 2008.

QUEIROZ, H. L. Preguiças e Guaribas; os mamíferos folívoros arborícolas do Mamirauá. Brasília: CNPq e Sociedade Civil Mamirauá, p. 176, 1995.

SILVA, G. A. O., PAZ, M. C. P., CORDEIRO, T. A. Monitoramento do bichopreguiça Bradypus variegatus Schinz, 1825 (Xenarthra: Bradypodidae) em um remanescente de Floresta Atlântica (João Pessoa-PB), Nordeste do Brasil. Revista Brasileira de Gestão Ambiental e Sustentabilidade 4(8): 299-312, 2017. Disponível em: http://revista.ecogestaobrasil.net/v4n8/v04n08a05.pdf Acesso em: 13 de outubro de 2020.

SPSS Inc. Released 2007. SPSS for Windows, Version 14.0. Chicago, SPSS Inc. 